\title{
MicroRNA - Mediated Regulation of Apoptosis in Osteosarcoma
}

\section{Masako Shimada*}

Endocrine Unit, Massachusetts General Hospital and Department of Medicine, Harvard Medical School, Boston, Massachusetts, 02114, USA

\begin{abstract}
Osteosarcoma is the most common primary bone cancer that predominantly affects children and young adolescents. Despite the progress in understanding the pathophysiology of osteosarcoma, it remains gravely influencing mobility and mortality of those young patients. A balance between cell proliferation and apoptosis is often dysregulated in cancer; tumor cells often show accelerated proliferation and reduced apoptosis, resulting in uncontrolled cancer cell growth. The recent discovery of microRNAs has added an exciting new layer of research interest in the fields of medical research in general including cancer. miRNAs are a class of 22 25 nucleotide non-coding RNAs that play a critical role in epigenetic modification of physiological functions of their target genes. Various pathway-specific and tumor-specific miRNAs have been identified and the mechanisms, by which they regulate pathological characteristics of cancer cells, have been elucidated intensively during the past several years. In this review, we summarize current knowledge of apoptosis-related miRNAs in osteosarcoma and their future therapeutic potentials.
\end{abstract}

Keywords: Osteosarcoma; MicroRNA; Apoptosis

\section{Introduction}

Osteosarcoma is the most common primary bone tumor that occurs predominantly in adolescents and young adults [1,2]. Advances in osteosarcoma therapy have improved patient outcomes; the most effective current therapeutic regimens include neoadjuvant and adjuvant chemotherapy combined with local limb-preserving surgery [3]. However, overall clinical outcomes remain poor especially for patients with metastasis and recurrent osteosarcoma. Therefore, it is important to address the unmet needs and continue searching for more effective therapeutic strategies. Apoptosis is the process of programmed cell death regulated by extrinsic and intrinsic inducers. In cancer cells, a balance between cell proliferation and apoptosis is often altered; we observe accelerated proliferation and reduced apoptosis of tumor cells, resulting in uncontrolled cancer cell growth. Two direct initiation pathways for apoptosis have been suggested; Tumor Necrosis Factor (TNF) [4] and Fas-Fas ligand (FasL) [5] pathways. Activation of those receptors signals to proapoptotic (Bax, Bid, Bak, and Bad) and antiapoptotic (Bcl-Xl and Bcl-2) members of the Bcl-2 family [6], and leads to stimulation of initiator and effector caspases [7]. Other key players in apoptosis in tumor cells include the tumor-suppressor protein, p53, which has been shown to be associated with various cancers including osteosarcoma [8]. p53 regulates the expression of various genes such as cyclin-dependent kinase inhibitor $1 \mathrm{~A}$ (p21) and modulates 4 cell proliferation, apoptosis, and senescence [9], and its reduced expression are also known to be closely associated with cancer. microRNAs (miRNAs) are a class of 22 25 nucleotide non-coding RNAs that play a critical role in regulation of various biological functions [10,11]. miRNAs bind to complementary sequences in the 3 '-untranslated region ( $3^{\prime}$-UTR) of the target gene transcripts and regulate their gene expression and function including apoptosis of tumor cells [12]. miRNA can function as tumor suppressors and oncogenes [13]. Dysregulation of miRNA expression has been reported in various human cancers including colon cancer [14], breast cancer [15,16], prostate cancer [1719], hepatocellular carcinoma [20-22], and osteosarcoma. Intensive studies during the last several years have identified numerous affected miRNAs in association with apoptosis, their target genes and biological functions, and possible drug interventions. Here, we will review recent progress of research on miRNA-mediated regulation of apoptosis in osteosarcoma and its future therapeutic applications.

\section{p53-related miRNAs}

In normal cells, p53 is inactivated by binding to its antagonist, mdm2; however, upon the DNA damage induced by irradiation, hypoxia, and osmotic stress, p53 dissociates from p53-specific E2ubiquitin protein ligase, $\mathrm{mdm} 2$, resulting in activation of $\mathrm{p} 53$. Activated p53 then induces cell cycle arrest and apoptosis to repair and discard the damaged cells. More than $20 \%$ of osteosarcoma showed mutation of the p53 gene [23]. Thus, to identify p53-responsive miRNAs associated with osteosarcoma, Braun et al. treated osteosarcoma cell lines with p53-agonist (nutlin-3) and -antagonist (mdm2), followed by miRNA array analysis, and identified miRNA-34a, miRNA-194, and miRNA-130 as p53-responsive miRNAs [24]. Further analysis revealed that miRNA-194, not miRNA-130, is consistently induced by p53 and is originated from two different RNA clusters, miRNA-194-1/ miRNA-192 on chromosome 11 and miRNA-194-2/miRNA-214 on chromosome 1. Overexpression of miRNA-192 and miRNA-215 together with miRNA-194, increases expression of p53 and p21 when compared with miRNA-34a as a positive control in osteosarcoma cell lines. These results demonstrated that p53-responsive miRNA-192 and miRNA-215 can act as effectors and regulators of p53, and suppress carcinogenesis by cell cycle arrest mediated by $\mathrm{p} 21$. They characterized that miRNA-34s are also direct targets of p53 in osteosarcoma using two osteosarcoma cell lines, p53-positive U2OS and p53-negative SaOS2 [25]. They found that both U2OS and SaOS-2 cells express miRNA$34 \mathrm{~s}$ at similar levels in a basal condition; however, irradiation- and 6 adriamycin-induced miRNA-34s expression was observed in p53-

*Corresponding author: Masako Shimada, Thier 10, 50 Blossom Street, Boston, MA 02114, USA, Tel: 1-(617)-726-3966; Fax: 1-(617)-726-1703; E-mail: shimada@helix.mgh.harvard.edu

Received March 08, 2013; Accepted March 21, 2013; Published April 01, 2013

Citation: Shimada M (2013) MicroRNA-Mediated Regulation of Apoptosis in Osteosarcoma. J Carcinogene Mutagene S6: 001. doi:10.4172/2157-2518.S6-001

Copyright: (c) 2013 Shimada M. This is an open-access article distributed under the terms of the Creative Commons Attribution License, which permits unrestricted use, distribution, and reproduction in any medium, provided the original author and source are credited. 
positive U2OS cells but not in p53-negative SaOS-2 cells. Thus, miRNA$34 \mathrm{~s}$ reduce the expression of cell cycle and apoptotic regulators, CDK6, $\mathrm{E} 2 \mathrm{~F} 3$, Cyclin E2, and Bcl-2, at least in part, in a p53-dependent manner, and result in miRNA-34s mediated G1 arrest and apoptosis. Moreover, they showed that expression of miRNA-34a, $3 b$, and $3 c$ is reduced and that increased levels of miRNA-34b/c DNA methylation are found in human osteosarcoma samples. Taken together, miRNA-34s are p53regulated miRNAs and undergo genetic and epigenetic alterations in osteosarcoma. Lastly, it was shown that miRNA-31 targets various genes including serine threonine kinase (STK) 40, E2F2, and CEBPA, and synergistically regulates cell proliferation and apoptosis of tumor cells of ovarian cancer through the E2F and p53 pathways [17]. The similar mechanism was also confirmed in an osteosarcoma cell line; U2OS cells, which exhibit normal p53 but inactivated mutant CDK2A gene encoding p14 and p16. U2OS cells also showed that miRNA-31 expression inhibits cell proliferation likely due to the impaired p53 pathway [17]. Collectively, miRNAs-31, 34s, 192, 194, and 215 are microRNAs, which can affect p53-associated apoptotic pathway in osteosarcoma cells.

\section{miRNA-17-92 cluster at chromosome 13 and chromosome $14 q 32$ miRNAs}

The human miRNA17-92 cluster encodes 6 miRNAs, miRNA-17, miRNA-18a, miRNA-19a, miRNA-19b, miRNA-20a, and miRNA-92 in chromosome 13 (C13Orf25) [26]. Overexpression of the cluster miRNA has been shown to promote cell proliferation [27-29], inhibit apoptosis [28,29] and oncogene induced senescence [30]. Huang et al. showed that miRNA-20a encoded by miRNA-17-92 cluster has an anti-apoptotic effect and it is also expressed in metastatic osteosarcoma [31]. Expression of miRNA-20a is negatively correlated with Fas expression and results in reduction of Fas/FasL-stimulated apoptosis in osteosarcoma.

Baumhoer et al. showed, using 6 well-established osteosarcoma cell lines, that miRNA-17-92 cluster deregulates various genes involved in cell differentiation (RGMB, LRRC17), cell cycle (CCNE1), and apoptosis (LIMA1, CAMK2N1) in osteosarcoma [32].

Next, Thayvanithy et al. reported that a subset of miRNAs at the chromosome 14q32 including miRNAs-382, 369-3p, 544, and 134, is down-regulated in osteosarcoma and that those miRNAs could target cMYC transcript [33]. Inversely, restoration of those miRNAs, decreases cMYC expression and induces apoptosis in $\mathrm{SaOS} 2$ cells with lower miRNA-17-92 expression on the chromosome 14q32. Thus, some of the miRNAs encoded by the chromosome 14q32 can modify cell proliferation and apoptosis by regulating cMYC.

Furthermore, osteosarcoma samples do not show consistent changes in methylation pattern in the $14 \mathrm{q} 32$ miRNA locus; however, down-regulation of the $14 \mathrm{q} 32$ miRNAs is associated with histon deacetylation in osteosarcoma cells [34]. Treatment of osteosarcoma cells with a drug, which increases acetylation, partially restores the 14q32 miRNA expression. An additional use of a drug, which increases methylation, interestingly, fully restores the gene expression pattern similar to that of normal osteoblastic cells in osteosarcoma cells.

Conversely, the combined usage of the DNA acetylation inhibitor and the DNA methylation inhibitor induces more aggressive cytotoxicity in osteosarcoma cells. These results suggest that $14 \mathrm{q} 32$ miRNA expression is dysregulated in osteosarcoma cells partially through its epigenetic modification including DNA acetylation and, at less extent, methylation.
Thus, the two cluster miRNAs at chromosome 13 and 14 also regulate cell cycle, apoptosis, metastatic potentials, and epigenetic modifications in osteosarcoma cells.

\section{Other miRNAs}

miRNA-15a and miRNA-16-1: Cyclin D1 encoded by CCND1 is a target of miRNA-15a and miRNA-16-1 [35]. Those miRNAs suppress CCND1 transcription by directly binding to the CCND1 3'-UTR and reduces cell proliferation in osteosarcoma.

miRNA-29s: Expression levels of miRNA-29a and miRNA-29b are down-regulated in most of osteosarcomas. Zhang et al. showed that miRNA-29a, unlike miRNA-29b and miRNA-29c, induces apoptosis independent of p53 expression by silencing Bcl-2 and Mcl-1 and increasing E2F1 and E2F3 expression [36].

miRNA-93: Higher miRNA-93 expression was found in 143B and primary osteosarcoma cells. Up-regulation of mRNA and protein expression of E2F1, one of the potential targets of miRNA-93, is detected in osteosarcoma [37].

miRNA-143: miRNA-143 was reported to be down-regulated in some cancer. Zhang et al. showed that 1) miRNA-143 is also downregulated in human osteosarcoma samples and cell lines, and that 2) its overexpression promotes cell apoptosis in human osteosacome cell lines, MG63 and U2OS cells. 3) Using luciferase reporter assay, they then displayed that miRNA-143 binds directly to two Bcl-2 3'-UTR sites as predicted by TargetScan prediction and inhibits expression of Bcl-2 in osteosarcoma [38]. Collectively, miRNA 143 negatively regulates expression of anti-apoptotic protein, $\mathrm{Bcl}-2$.

miRNA-221: Expression of miRNA-221 is up-regulated in osteosarcoma cell lines. miRNA-221 expression increases cell survival and cisplatin-resistance and reduces apoptosis [39]. Further, PTEN is determined to be a direct target of miRNA-221. miRNA-221 directly binds to PTEN 3'-UTR, inhibits PTEN translation, and activates the Akt pathway. Several downstream targets of the Akt pathway including CCND1, p27, and Bcl-2, were also regulated by miRNA-221. Inverse correlation between miRNA-221 and PTEN levels has been shown in osteosarcoma. Thus, miRNA-221 induces cell survival and cisplatinresistance at least partially by modulating the PI3K/PTEN/Akt pathway.

miRNA-223: Heat shock protein 90B1 (HSP90B1) is a direct target of miRNA-223. miRNA-223 may have tumor suppressor function through the PI3K/Akt/mTOR pathway in osteosarcoma [40].

\section{Conclusions}

Recent evidence has shown various apoptosis-related miRNAs and their molecular targets in osteosarcoma (Table 1). Some miRNAs serve as oncogenes, which are found up-regulated, and others do as tumor suppressors, which are often down-regulated, in osteosarcoma cells. Several lines of studies have indicated that targeting specific miRNAs could have therapeutic potentials because of their tumor and pathway specificity. Therefore, the next possible therapeutic approaches could be developed to block the expression of oncogenic miRNAs using, for example, antisense-oligonucleotides targeted for the specific miRNAs, and restore the expression of tumor suppressor miRNAs by using miRNA mimics in treatment of osteosarcoma. Moreover, delivery methods of those antisense-oligonucletides and miRNA mimics could be further developed from systemic administration [13,41] to local targeted delivery to the tumors using the latest technology such as nanoparticles [41] in the future. 
Citation: Shimada M (2013) MicroRNA-Mediated Regulation of Apoptosis in Osteosarcoma. J Carcinogene Mutagene S6: 001. doi:10.4172/21572518.S6-001

\begin{tabular}{|c|c|c|c|c|c|}
\hline microRNAs & Target genes & Chromosome & Function & Cell lines & Citations \\
\hline $\begin{array}{l}\text { miR-34a } \\
\text { miR-192 } \\
\text { miR-215 }\end{array}$ & Cdkn1A/p21 & $\begin{array}{l}\operatorname{miR}-192 / 194 ; 11 \\
\text { miR-215/194; } 1\end{array}$ & $\begin{array}{l}\text { Increase apoptosis } \\
\text { Cell cycle arrest } \\
\text { Suppress carcinogenesis }\end{array}$ & & {$[24]$} \\
\hline miR-34s & $\begin{array}{l}\text { CDK6, E2F3 } \\
\text { Cyclin E2, Bcl-2 }\end{array}$ & $\begin{array}{l}\text { miRNA-34a; 1p36 } \\
\text { miRNA-34b/34c; 11q23 }\end{array}$ & $\begin{array}{l}\text { Cell cycle arrest } \\
\text { Apoptosis }\end{array}$ & $\begin{array}{l}\text { U2OS } \\
\text { SaOS2 }\end{array}$ & [25] \\
\hline miR-31 & $\begin{array}{l}\text { E2F2, p14 } \\
\text { p16 }\end{array}$ & $9 p 21.3$ & $\begin{array}{l}\text { Cell cycle, Promote p53 activity, Induce } \\
\text { apoptosis }\end{array}$ & U2OS & {$[30]$} \\
\hline $\begin{array}{l}\text { 14q32 miRs (miR-382, } \\
369-3 p, 544,134)\end{array}$ & $\begin{array}{l}\text { cMyc } \\
\text { miR-17-92 }\end{array}$ & $14 q 32$ & Pro-apoptotic effect & SaOS2 & [33] \\
\hline miR-20a & Fas & C13orf25 & $\begin{array}{l}\text { Induce metastasis } \\
\text { Reduce Fas-mediated apoptosis }\end{array}$ & $\begin{array}{l}\text { LM7 } \\
\text { SaOS2 }\end{array}$ & [31] \\
\hline miR-17-92 & $\begin{array}{l}\text { LRRC17, RGMB, LIMA1, } \\
\text { CCNE1, VAMK2N1 }\end{array}$ & C13orf25 & $\begin{array}{l}\text { Oncogenic \& tumor suppressor properties, } \\
\text { Differentiation, Apoptosis, Cell cycle regulation }\end{array}$ & $\begin{array}{l}\text { HOS58, U2OS, SaOS2, } \\
\text { SJSA1, MG63 }\end{array}$ & {$[32]$} \\
\hline 14q32 miRs & HDAC & $14 q 32$ & Elevate histone deacetylase activity & $\mathrm{SaOS} 2$ & {$[34]$} \\
\hline $\begin{array}{l}\text { miR-15 } \\
\text { miR16-1 }\end{array}$ & CCND1 & & Apoptosis, Cell cycle arrest & SOSP-9607 & [35] \\
\hline miR-29a & $\mathrm{Bcl}-2, \mathrm{Mcl}-1, \mathrm{E} 2 \mathrm{~F} 1, \mathrm{E} 2 \mathrm{~F} 3$ & & $\begin{array}{l}\text { Down-regulated in Osteosarcoma, Induce } \\
\text { apoptosis (p53-independent) Down-regulate } \\
\text { Bcl-2, Mcl-1, Increase tumor suppressor genes, } \\
\text { E2F1 and E2F3 }\end{array}$ & $\begin{array}{l}\text { U2OS } \\
\text { SaOS2 }\end{array}$ & [36] \\
\hline miR-93 & E2F1 & & $\begin{array}{l}\text { Reduce cell viability, Promote apoptosis, } \\
\text { Suppress tumorigenesis }\end{array}$ & MG63, 143B & {$[37]$} \\
\hline miR-143 & $\mathrm{Bcl}-2$ & & & MG63, U2OS & [38] \\
\hline miR-221 & PTEN & & $\begin{array}{l}\text { Increase cell survival and cisplatinresistance, } \\
\text { Decrease apoptosis }\end{array}$ & $\begin{array}{l}\text { SOSP-9607, } \\
\text { MG63 }\end{array}$ & [39] \\
\hline miR-223 & $\begin{array}{l}\text { Heat shock } \\
\text { protein } \\
\text { 90B1(HSP90B1) }\end{array}$ & & $\begin{array}{l}\text { Suppress HSP90B1 and cell growth, Cell cycle } \\
\text { arrest and apoptosis. Decrease PI3K/Akt/mTOR/ } \\
\text { Bcl-2. Increase Bid }\end{array}$ & MG63 & {$[40]$} \\
\hline
\end{tabular}

Table 1: Apoptosis-related microRNAs in osteosarcoma.

\section{Acknowledgements}

This work is supported by Milton Fund from Harvard University to MS.

\section{References}

1. Mirabello L, Troisi RJ, Savage SA (2009) Osteosarcoma incidence and survival rates from 1973 to 2004: data from the Surveillance, Epidemiology, and End Results Program. Cancer 115: 1531-1543.

2. Geller DS, Gorlick R (2010) Osteosarcoma: a review of diagnosis, management and treatment strategies. Clin Adv Hematol Oncol 8: 705-718.

3. Marina N, Gebhardt M, Teot L, Gorlick R (2004) Biology and therapeutic advances for pediatric osteosarcoma. Oncologist 9: 422-441.

4. Chen G, Goeddel DV (2002) TNF-R1 signaling: a beautiful pathway. Science 296: 1634-1635.

5. Wajant $\mathrm{H}$ (2002) The Fas signaling pathway: more than a paradigm. Science 296: 1635-1636.

6. Murphy KM, Ranganathan V, Farnsworth ML, Kavallaris M, Lock RB (2000) $\mathrm{Bcl}-2$ inhibits Bax translocation from cytosol to mitochondria during druginduced apoptosis of human tumor cells. Cell Death Differ 7: 102-111.

7. Yuan Y, Zhang YS, Qu X (2011) The Molecular Alterations Regarding Apoptosis in Hapatocellular Carcinoma Cells at a Glance. J Carcinogene Mutagene: 12

8. Pompetti F, Stuppia L, Gatta V, Calabrese G, Gamberi G, et al. (1998) Correlation between apoptosis and TP53 status in osteosarcoma. Cancer Genet Cytogenet 105: 177-181

9. el-Deiry WS, Tokino T, Velculescu VE, Levy DB, Parsons R, et al. (1993) WAF1, a potential mediator of p53 tumor suppression. Cell 75: 817-825.

10. Bartel DP (2004) MicroRNAs: genomics, biogenesis, mechanism, and function Cell 116: 281-297.

11. Kim VN (2005) Small RNAs: classification, biogenesis, and function. Mol Cells 19: $1-15$

12. Wu L, Belasco JG (2008) Let me count the ways: mechanisms of gene regulation by miRNAs and siRNAs. Mol Cell 29: 1-7.

13. Nana-Sinkam SP, Croce CM (2011) MicroRNAs as therapeutic targets in cancer. Transl Res 157: 216-225.
14. Bandrés E Cubedo $E$, Agirre X Malumbres $R$, Zárate $R$, et al. (2006) Identification by Real-time PCR of 13 mature microRNAs differentially expressed in colorectal cancer and non-tumoral tissues. Mol Cancer 5: 29

15. Garcia Al, Buisson M, Bertrand P, Rimokh R, Rouleau E, et al. (2011) Downregulation of BRCA1 expression by miR-146a and miR-146b-5p in triple negative sporadic breast cancers. EMBO Mol Med 3: 279-290.

16. Lyng MB, Lænkholm AV, Søkilde R, Gravgaard KH, Litman T, et al. (2012) Global microRNA expression profiling of high-risk ER+ breast cancers from patients receiving adjuvant tamoxifen mono-therapy: a DBCG study. PLoS One 7: e36170

17. Creighton CJ, Fountain MD, Yu Z, Nagaraja AK, Zhu H, et al. (2010) Molecula profiling uncovers a p53-associated role for microRNA-31 in inhibiting the proliferation of serous ovarian carcinomas and other cancers. Cancer Res 70 : 1906-1915.

18. Porkka KP, Ogg EL, Saramäki OR, Vessella RL, Pukkila H, et al. (2011) The miR-15a-miR-16-1 locus is homozygously deleted in a subset of prostate cancers. Genes Chromosomes Cancer 50: 499-509.

19. Tong AW, Fulgham P, Jay C, Chen P, Khalil I, et al. (2009) MicroRNA profile analysis of human prostate cancers. Cancer Gene Ther 16: 206-216.

20. Donsante A, Miller DG, Li Y, Vogler C, Brunt EM, et al. (2007) AAV vecto integration sites in mouse hepatocellular carcinoma. Science 317: 477.

21. Gramantieri L, Ferracin M, Fornari F, Veronese A, Sabbioni S, et al. (2007) Cyclin G1 is a target of miR-122a, a microRNA frequently down-regulated in human hepatocellular carcinoma. Cancer Res 67: 6092-6099.

22. Huang YS, Dai Y, Yu XF, Bao SY, Yin YB, et al. (2008) Microarray analysis of microRNA expression in hepatocellular carcinoma and non-tumorous tissues without viral hepatitis. J Gastroenterol Hepatol 23: 87-94

23. Ta HT, Dass CR, Choong PF, Dunstan DE (2009) Osteosarcoma treatment: state of the art. Cancer Metastasis Rev 28: 247-263.

24. Braun CJ, Zhang X, Savelyeva I, Wolff S, Moll UM, et al. (2008) p53-Responsive micrornas 192 and 215 are capable of inducing cell cycle arrest. Cancer Res 68: 10094-10104.

25. He C, Xiong J, Xu X, Lu W, Liu L, et al. (2009) Functional elucidation of MiR34 in osteosarcoma cells and primary tumor samples. Biochem Biophys Res Commun 388: 35-40. 
Citation: Shimada M (2013) MicroRNA-Mediated Regulation of Apoptosis in Osteosarcoma. J Carcinogene Mutagene S6: 001. doi:10.4172/21572518.S6-001

26. Ota A, Tagawa H, Karnan S, Tsuzuki S, Karpas A, et al. (2004) Identification and characterization of a novel gene, C13orf25, as a target for 13q31-q32 amplification in malignant lymphoma. Cancer Res 64: 3087-3095.

27. Hayashita Y, Osada H, Tatematsu Y, Yamada H, Yanagisawa K, et al. (2005) A polycistronic microRNA cluster, miR-17-92, is overexpressed in human lung cancers and enhances cell proliferation. Cancer Res 65: 9628-9632.

28. He L, Thomson JM, Hemann MT, Hernando-Monge E, Mu D, et al. (2005) A microRNA polycistron as a potential human oncogene. Nature 435: 828-833.

29. Venturini L, Battmer K, Castoldi M, Schultheis B, Hochhaus A, et al. (2007) Expression of the miR-17-92 polycistron in chronic myeloid leukemia (CML) CD34+ cells. Blood 109: 4399-4405

30. Hong L, Lai M, Chen M, Xie C, Liao R, et al. (2010) The miR-17-92 cluster of microRNAs confers tumorigenicity by inhibiting oncogene-induced senescence. Cancer Res 70: 8547-8557.

31. Huang G, Nishimoto K, Zhou Z, Hughes D, Kleinerman ES (2012) miR$20 \mathrm{a}$ encoded by the miR-17-92 cluster increases the metastatic potential of osteosarcoma cells by regulating Fas expression. Cancer Res 72: 908-916.

32. Baumhoer D, Zillmer S, Unger K, Rosemann M, Atkinson MJ, et al. (2012) MicroRNA profiling with correlation to gene expression revealed the oncogenic miR-17-92 cluster to be up-regulated in osteosarcoma. Cancer Genet 205 212-219.

33. Thayanithy V, Sarver AL, Kartha RV, Li L, Angstadt AY, et al. (2012) Perturbation of 14q32 miRNAs-cMYC gene network in osteosarcoma. Bone 50: 171-181.

34. Thayanithy V, Park C, Sarver AL, Kartha RV, Korpela DM, et al. (2012)
Combinatorial treatment of DNA and chromatin-modifying drugs cause cel death in human and canine osteosarcoma cell lines. PLoS One 7: e43720.

35. Cai CK, Zhao GY, Tian LY, Liu L, Yan K, et al. (2012) miR-15a and miR16-1 downregulate CCND1 and induce apoptosis and cell cycle arrest in osteosarcoma. Oncol Rep 28: 1764-1770.

36. Zhang W, Qian JX, Yi HL, Yang ZD, Wang CF, et al. (2012) The microRNA-29 plays a central role in osteosarcoma pathogenesis and progression. Mol Biol (Mosk) 46: 622-627.

37. Montanini L, Lasagna L, Barili V, Jonstrup SP, Murgia A, et al. (2012) MicroRNA cloning and sequencing in osteosarcoma cell lines: differential role of miR-93. Cell Oncol (Dordr) 35: 29-41.

38. Zhang H, Cai X, Wang Y, Tang H, Tong D, et al. (2010) microRNA-143, downregulated in osteosarcoma, promotes apoptosis and suppresses tumorigenicity by targeting Bcl-2. Oncol Rep 24: 1363-1369.

39. Zhao G, Cai C, Yang T, Qiu X, Liao B, et al. (2013) MicroRNA-221 induces cell survival and cisplatin resistance through PI3K/Akt pathway in human osteosarcoma. PLoS One 8: e53906.

40. Li G, Cai M, Fu D, Chen K, Sun M, et al. (2012) Heat shock protein 90B1 plays an oncogenic role and is a target of microRNA-223 in human osteosarcoma. Cell Physiol Biochem 30: 1481-1490.

41. Chen Y, Zhu X, Zhang X, Liu B, Huang L (2010) Nanoparticles modified with tumor-targeting scFv deliver siRNA and miRNA for cancer therapy. Mol Ther 18: $1650-1656$

This article was originally published in a special issue, Apoptosis handled by Editor(s). Dr. Nancy Turner, Texas A\&M University, USA 